\title{
Radiocarbon-based impact assessment of open biomass burning on regional carbonaceous aerosols in North China
}

\author{
Zheng Zong a,c , Yingjun Chen ${ }^{\text {a,* }}$, Chongguo Tian ${ }^{\text {a,* }}$, Yin Fang ${ }^{\text {a }}$, Xiaoping Wang ${ }^{\text {b,c }}$, Guopei Huang ${ }^{\text {a }}$, Fan Zhang ${ }^{\text {a }}$ \\ Jun Li ${ }^{\mathrm{b}}$, Gan Zhang ${ }^{\mathrm{b}}$
}

a Key Laboratory of Coastal Environmental Processes and Ecological Remediation, Yantai Institute of Coastal Zone Research, Chinese Academy of Sciences, Yantai 264003, China

b State Key Laboratory of Organic Geochemistry, Guangzhou Institute of Geochemistry, Chinese Academy of Sciences, Guangzhou 510640, China

c Graduate University of Chinese Academy of Sciences, Beijing 100039, China

\section{H I G H L I G H T S}

- $\mathrm{PM}_{2.5}$ and TSP samples collected at Yellow River Delta were analyzed for OC and EC.

- OC, EC, TSP and $\mathrm{PM}_{2.5}$ concentrations were higher in daytime than in nighttime.

- Radiocarbon $\left({ }^{14} \mathrm{C}\right)$ tracer, backward trajectories, and fire counts were used for the analysis.

- Agricultural waste open burning was a main contributor to summer $\mathrm{PM}_{2.5}$, OC and EC.

\section{A R T I C L E I N F O}

\section{Article history:}

Received 30 October 2014

Received in revised form 30 December 2014

Accepted 5 January 2015

Available online 3 March 2015

Editor: P. Kassomenos

\section{Keywords:}

Radiocarbon $\left({ }^{14} \mathrm{C}\right)$ tracer

Organic carbon

Elemental carbon

Open crop residue burning

\begin{abstract}
A B S T R A C T
Samples of total suspended particulates (TSPs) and fine particulate matter $\left(\mathrm{PM}_{2.5}\right)$ were collected from 29th May to 1 st July, 2013 at a regional background site in Bohai Rim, North China. Mass concentrations of particulate matter and carbonaceous species showed a total of $50 \%$ and $97 \%$ of the measured TSP and $\mathrm{PM}_{2.5}$ levels exceeded the first grade national standard of China, respectively. Daily concentrations of organic carbon (OC) and elemental carbon (EC) were detected 7.3 and $2.5 \mu \mathrm{g} \mathrm{m}^{-3}$ in TSP and 5.2 and $2.0 \mu \mathrm{g} \mathrm{m}^{-3}$ in $\mathrm{PM}_{2.5}$, which accounted $5.8 \%$ and $2.0 \%$ of TSP while $5.6 \%$ and $2.2 \%$ for $\mathrm{PM}_{2.5}$, respectively. The concentrations of OC, EC, TSP and $\mathrm{PM}_{2.5}$ were observed higher in the day time than those in the night time. The observations were associated with the emission variations from anthropogenic activities. Two merged samples representing from south and north source areas were selected for radiocarbon analysis. The radiocarbon measurements showed $74 \%$ of water-insoluble OC (WINSOC) and $59 \%$ of EC in $\mathrm{PM}_{2.5}$ derived from biomass burning and biogenic sources when the air masses were from south region, and $63 \%$ and $48 \%$ for the air masses from north, respectively. Combined with backward trajectories and daily burned area, open burning of agricultural wastes was found to be predominating, which was confirmed by the potential source contribution function (PSCF).
\end{abstract}

(C) 2015 Elsevier B.V. All rights reserved.

\section{Introduction}

Carbonaceous aerosols are now of worldwide concern for their direct and indirect impacts on global and regional climate change, visibility degradation, air quality, and public health (Anenberg et al., 2012; Chung et al., 2012; Mahowald, 2011). Elemental carbon (EC) and organic carbon $(\mathrm{OC})$ are two main fractions of carbonaceous species in the air Particulate EC derives from the incomplete combustion of fossil fuels such as coal, gasoline, diesel, and biomass (i.e., vegetation and wood). Particulate OC originates from anthropogenic and biogenic sources, including primary organic carbon (POC) emitted from the incomplete

\footnotetext{
* Corresponding authors at: Yantai Institute of Coastal Zone Research, CAS, China. E-mail addresses: yjchen@yic.ac.cn (Y. Chen), cgtian@yic.ac.cn (C. Tian).
}

combustion of carbon-contained material and primary biogenic source. While secondary organic carbon (SOC) formed through both photochemical oxidation of volatile precursors and subsequent gas-toparticle conversion processes (Fang et al., 2008). It is a critical job to quantify these sources for the development of effective and efficient air pollution control measures, especially in the areas with rapid economic growth and high population density where large amounts of those species are released into the air.

The Bohai Rim has become the third largest economic zone after the Yangtze River Delta and the Pearl River Delta in China (Xin et al., 2011). It is located in the northern China around Bohai Sea and comprises Beijing and Tianjin municipalities as well as part of Hebei, Liaoning and Shandong provinces. This region has been facing serious air pollution problems (including carbonaceous aerosols) (Boynard et al., 2014), due to dramatic increase in urbanization, industrialization and 
large-scale farming activities in the recent years. Some statistical methods, such as positive matrix factorization, eigenvector model and chemical mass balance model were used to identify the sources of carbonaceous aerosols in the region. However, significant difference was found from previous source apportionment assessments, such as about quarter (Q. Wang et al., 2009) and half (Cheng et al., 2013) of the carbon fractions in Beijing were associated with biomass burning processes. The uncertainty of the source apportionment results strongly depend on the temporal and spatial variations of emission sources such as source profiles, source strength, and nonlinear environmental processes (atmospheric advection/diffusion and chemical reactions).

Radiocarbon $\left({ }^{14} \mathrm{C}\right)$ measurements provide a chance to differentiate between fossil and non-fossil sources of carbonaceous particles because the carbon isotopic composition in the ambient aerosol remains stable during atmospheric transport and chemical transformations (Sun et al., 2012). Recently, as a powerful tool, this method has been used to distinguish fossil and non-fossil sources in the Chinese cities (Chen et al., 2013; Huang et al., 2014; Liu et al., 2014) or rural sites (Liu et al., 2013; Zhang et al., 2014b). The previous results showed that $83 \%$ of EC in Beijing are from fossil fuel usage, such as coal burning and vehicle exhaust (Chen et al., 2013; Sun et al., 2012). However, available knowledge of emission sources of carbonaceous aerosols on regional scale in the Bohai Rim is still poorly understood.

Previously monitoring data from a background area which has not been contaminated by certain preponderant source emissions are often used to assess the source apportionment of the regional pollution (Puxbaum et al., 2007; Wang et al., 2014; Zhang et al., 2010). In this work, total suspended particulate (TSP) and fine particulate matter $\left(\mathrm{PM}_{2.5}\right)$ samples were collected in summer, 2013 at the Yellow River Delta, North China. This is a regional background receptor site in the Bohai Rim, which is influenced by seasonally air pollution outflows from Beijing, Tianjin and Hebei (BTH) and Shandong, Henan and Jiangsu province (SHJ) under the East winter and summer monsoon. The objectives of this study are 1) to assess the concentration levels and intraday variations of particulate matter and carbonaceous species at a background area in Bohai Rim; 2) to discriminate and quantify carbon originating from fossil fuel and non-fossil sources by using radiocarbon $\left({ }^{14} \mathrm{C}\right)$ measurements in different carbonaceous sub-fractions; and 3$)$ to assess the potential source area by the application of potential source contribution function (PSCF) and backward trajectories.

\section{Methodology}

\subsection{Sample location}

The sampling campaign was conducted in the Yellow River Delta Ecological Research Station of Coastal Wetland $\left(37^{\circ} 45^{\prime} \mathrm{N}, 118^{\circ} 59^{\prime} \mathrm{E}\right)$, Chinese Academy of Sciences as shown in Fig. 1. The station is located at about $3 \mathrm{~km}$ south to Yellow River channel and about $20 \mathrm{~km}$ southwest to the mouth of the Yellow River (Han et al., 2014). The sampling period was from 29 May to 1 July, 2013. During the sampling time, prevailing wind was from the south and air parcels arriving in the Yellow River Delta were mainly from the SHJ region dominated by the East Asian summer monsoon, which was illustrated by the backward trajectories as shown in supporting information (SI) Fig. S1.

\subsection{Sampling procedure}

$\mathrm{PM}_{2.5}$ and TSP samples were collected by using a Tisch high volume sampler at a flow rate of $1.13 \mathrm{~m}^{3} \mathrm{~min}^{-1}$ and a high volume sampler at a flow rate of $0.3 \mathrm{~m}^{3} \mathrm{~min}^{-1}$, respectively. The $\mathrm{PM}_{2.5}$ and TSP samples were collected on separate quartz filters by two time-resolutions ( $12 \mathrm{~h} \& 6 \mathrm{~h}$ ) in the sampling campaign. The 12 hour sample was collected from 6:00 to $18: 00$ (day time) and from 18:00 to $6: 00$ (night time) the next day. The 6 hourly sampling was from $6: 00$ to $12: 00,12: 00$ to 18:00, 18:00 to $24: 00$, and 0:00 to 6:00, respectively. Two 6-hourly interval sampling activities were performed from 1 st $(18: 00)$ to 4 th (18:00) and from 18th (18:00) to 21st (18:00) in June, 2013, and 24 pairs of $\mathrm{PM}_{2.5}$ and TSP samples were collected. The other samples were collected by the 12-hourly sampling and 52 samples were collected. A total of $76 \mathrm{PM}_{2.5}$ and 76 TSP samples were collected during the sampling period. All quartz filters were preheated at $450{ }^{\circ} \mathrm{C}$ for $6 \mathrm{~h}$ before sampling. The filters were wrapped in aluminum foil and sealed in polyethylene bags before and after the sample collection.

To obtain the mass concentrations of TSP and $\mathrm{PM}_{2.5}$, quartz fiber filters were analyzed gravimetrically using a Sartorius MC5 electronic microbalance with $\mathrm{a} \pm 1 \mu \mathrm{g}$ sensitivity. These filters were weighted after 24-h equilibration at $25{ }^{\circ} \mathrm{C}$ and $39 \%$ relative humidity. Each filter was weighed for at least three times before and after sampling. The difference among the three repeated weighing was less than $10 \mu \mathrm{g}$ for a blank filter and less than $20 \mu \mathrm{g}$ for a sampled filter. After weighing, loaded filters were stored in a refrigerator at $-20{ }^{\circ} \mathrm{C}$ before chemical

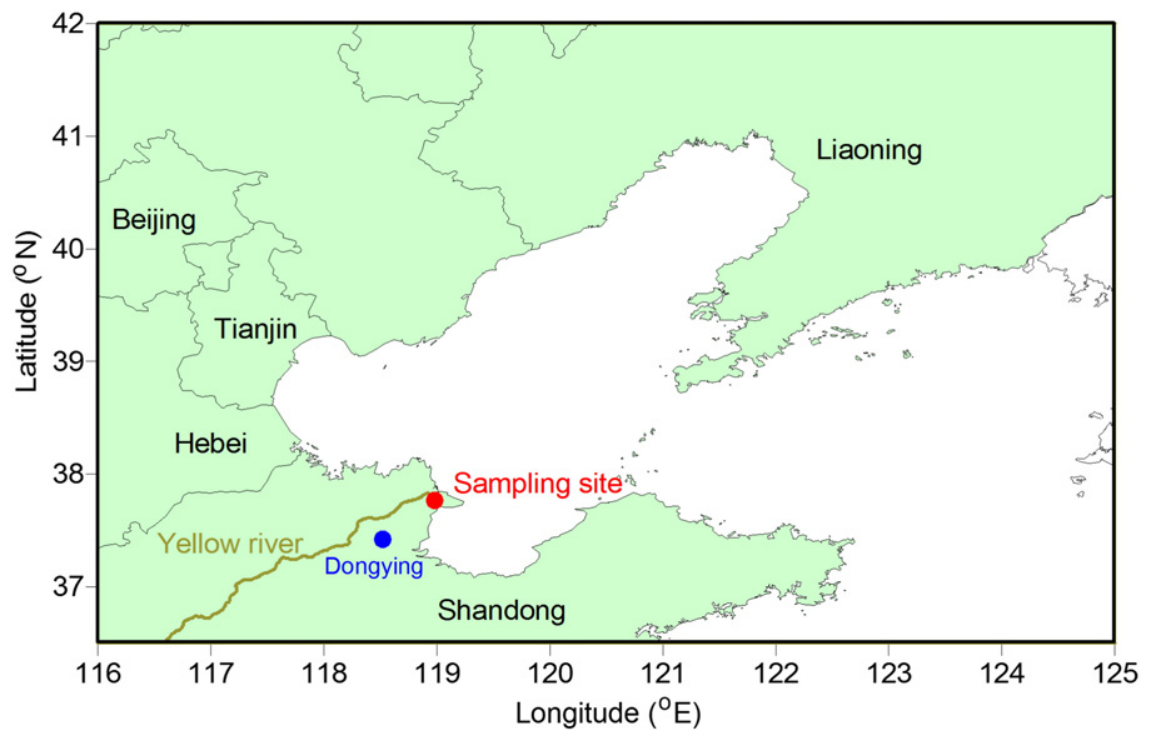

Fig. 1. The location of sampling site. 
analysis to prevent evaporation of volatile components. Also, field blank filters were collected to subtract the possible contamination that occurred during or after sampling.

\subsection{Thermal-optical carbon analysis}

After measurement of $\mathrm{PM}_{2.5}$ mass concentrations, carbonaceous components were analyzed by a Desert Research Institute (DRI) Model 2001 Carbon analyzer (Atmoslytic Inc., Calabasas, CA) following the Interagency Monitoring of Protected Visual Environment (IMPROVE) thermal/optical reflectance (TOR) protocol. The quartz filter collected particles was punched for specific size $\left(0.544 \mathrm{~cm}^{2}\right)$ then placed onto the sample load position of the analyzer. The sample was heated to produce four OC fractions $(O C 1, O C 2, O C 3$, and OC4) in four temperature steps (140, 280,480 , and $580{ }^{\circ} \mathrm{C}$ ) under a non-oxidizing helium atmosphere, as well as three EC fractions (EC1, EC2, and EC3) in three temperature steps $\left(580,740\right.$, and $840{ }^{\circ} \mathrm{C}$ ) under an oxidizing atmosphere of $2 \% \mathrm{O}^{2} /$ $98 \% \mathrm{He}$. At the same time, pyrolyzed organic carbon (OP) was produced in the inert atmosphere, which decreased the reflected light to correct for charred OC. Total OC is defined as the sum of the four OC fractions $(\mathrm{OC} 1, \mathrm{OC} 2, \mathrm{OC} 3$, and OC4) plus OP, and total EC is defined as the sum of the three EC fractions (EC1, EC2, and EC3) minus OP. The detection limits of the method for OC and EC were 0.82 and $0.20 \mu \mathrm{g} \mathrm{cm}{ }^{-2}$, respectively. 6 or 12 hour monitored data were averaged mathematically for the daily analysis.

Quality assurance and control (QA/QC) procedures were also performed during sample analysis. A sucrose solution of known concentration was tested to make sure that the error is within $5 \%$ every time before analyzing the samples. Blank filters and replicate samples were examined simultaneously in order to obtain their inherent concentrations on the filter and to evaluate measurement accuracy by using the same methods, respectively. Blank filters and replicate analyses were performed after analyzing a batch of 10 samples. The contribution of OC and EC from blank filters was $<3.5$ and $0.6 \%$ of their respective average concentrations in aerosol samples for both TSP and $\mathrm{PM}_{2.5}$, respectively. Comparison with average values from the replicate analyses showed a good precision with relative deviations of $5.7 \%$ and $4.9 \%$ for OC and EC in TSP, and 6.3\% and 7.9\% in $\mathrm{PM}_{2.5}$.

\section{4. ${ }^{14} \mathrm{C}$ Analysis of the carbonaceous fractions}

The measurement of the ${ }^{14} \mathrm{C}$ in the $\mathrm{OC}$ and $\mathrm{EC}$ was performed using the $\mathrm{OC} / \mathrm{EC}$ separation system described in the study of Liu et al. (Liu et al., 2013). Briefly, with respect to OC, the filters were all extracted with ultrapure water to remove any interfering water-soluble inorganic and organic compounds. Therefore, the ${ }^{14} \mathrm{C}$ values in the $\mathrm{OC}$ obtained in this work only represent the water-insoluble OC (WINSOC) and do not include the water-soluble OC. OC was isolated at $340{ }^{\circ} \mathrm{C}$ for $15 \mathrm{~min}$ after a flash heating of $650^{\circ} \mathrm{C}$ for $45 \mathrm{~s}$, which can minimize the charring that is primarily produced by incomplete combustion of the OC. After the OC separation, the filters were removed from the system, placed into a muffle furnace at $375^{\circ} \mathrm{C}$, and combusted for $4 \mathrm{~h}$ in order to remove the charring. Afterwards the filters were quickly put back into the system and oxidized under a stream of pure oxygen at $650{ }^{\circ} \mathrm{C}$ for $10 \mathrm{~min}$ to analyze the EC fraction. The carbon dioxide from WINSOC and EC was cryogenically trapped and sealed in a quartz tube for AMS target preparation. The preparation of graphite targets for accelerator mass spectrometry (AMS) analysis was performed using the graphitization line at the Guangzhou Institute of Geochemistry, CAS. The ${ }^{14} \mathrm{C} /{ }^{12} \mathrm{C}$ ratios in the graphite samples were determined through NEC compact AMS at Peking University.

In this study, samples collected in two typical days prevailing north and south wind respectively were selected to analyze ${ }^{14} \mathrm{C}$ of WINSOC and EC for studying the sources of carbonaceous aerosols.

\subsection{Air trajectory generation and burned area}

Backward trajectories and daily burned area were used to assess potential sources of observed carbonaceous aerosols in different air masses encountered during the sampling period. Backward trajectories were generated by the hybrid single-particle Lagrangian integrated trajectory (HYSPLIT) model, which is available on the National Oceanic and Atmospheric Administration Air Resource Laboratory website (www. arl.noaa.gov/ready/hysplit4.html) (Draxler and Rolph, 2003). Backward trajectories (72-h) were generated with $6 \mathrm{~h}$ time intervals. The trajectories were calculated for air masses starting from the sampling site at $10 \mathrm{~m}$ above ground level. The fourth generation of the Global Fire Emissions Database (GFED4) burned area was used to assess agricultural waste burning (Giglio et al., 2013). The GFED4 gridded $\left(0.25^{\circ}\right)$ daily burned area data sets are available through the web site http://www. globalfiredata.org.

\subsection{Potential source contribution function}

The potential source contribution function (PSCF) was also used to assess potential source areas contributing high concentrations of $\mathrm{PM}_{2.5}$, OC and EC in the $\mathrm{PM}_{2.5}$ samples (Y.Q. Wang et al., 2009). PSCF can be briefly described as conditional possibility and characterizing the spatial distribution of possible geophysical source locations made out by using trajectories reaching to the sampling site.

The ijth component of a PSCF field can be defined as given in Eq. (1) (Jeong et al., 2011);

$\operatorname{PSCF}_{i j}=m_{i j} / n_{i j}$

where $n_{i j}$ is the total number of end points that fall in the $\mathrm{ij}_{\mathrm{t}}$ cell and $\mathrm{m}_{\mathrm{ij}}$ is the number of endpoints for the $\mathrm{ij}_{\text {th }}$ cell with arrival times at the sampling site that correspond to each type of aerosol concentrations higher than an arbitrarily set criterion. The 75th percentile of the monitored concentrations of species of interest (OC: 6.82, EC: 2.96, PM2.5: $110.90 \mu \mathrm{g} \mathrm{m}^{-3}$ ) were utilized for PSCF calculations to identify the potential source areas.

In the PSCF method, cells with few endpoints may result in high uncertainty. Thus, to avoid uncertainties that can occur due to a limited amount of available data, an arbitrary weight function $\mathrm{W}\left(\mathrm{n}_{\mathrm{ij}}\right)$ as shown in Eq. (2) is multiplied with the PSCF value (Jeong et al., 2011).

$$
W\left(n_{i j}\right)= \begin{cases}1.00 & n \geq 24 \\ 0.75 & 6 \leq n<24 \\ 0.42 & 3 \leq n<6 \\ 0.05 & n<3\end{cases}
$$

\section{Results and discussion}

\subsection{Mass concentrations of TSP, $P M_{2.5}$ and carbonaceous species}

Table 1 lists statistical values of daily mean concentrations for TSP, $\mathrm{PM}_{2.5}$ and carbonaceous aerosols. During the sampling period, the mean concentration of TSP was $125.4 \mu \mathrm{g} \mathrm{m}^{-3}$ and ranged between 46.1 and $198.5 \mu \mathrm{g} \mathrm{m}^{-3}$, while the mean concentration of $\mathrm{PM}_{2.5}$ was $92.3 \mu \mathrm{g} \mathrm{m}^{-3}$ and ranged between 33.3 and $194.3 \mu \mathrm{g} \mathrm{m}{ }^{-3}$. Both monitored daily TSP and $\mathrm{PM}_{2.5}$ concentrations exceeded the First Grade National Ambient Air Quality Standard $\left(80 \mu \mathrm{g} \mathrm{m}^{-3}\right.$ for TSP and $35 \mu \mathrm{g} \mathrm{m}^{-3}$ for $\mathrm{PM}_{2.5}$ ) of China (Ministry of Environmental Protection of China: GB 3095-2012, www.zhb.gov.cn, 2012-02-29). The largest ratios of monitored concentrations to the first grade ambient air quality standard are 1.6 for TSP and 5.6 for $\mathrm{PM}_{2.5}$. Total number of sampling days exceeding the standard values accounts for $50 \%$ for TSP and $97 \%$ for $\mathrm{PM}_{2.5}$ during the whole sampling period. The ratio of $\mathrm{PM}_{2.5}$ to TSP 
Table 1

Statistical values of TSP, $\mathrm{PM}_{2.5}$, OC and EC concentrations $\left(\mu \mathrm{g} \mathrm{m}^{-3}\right)$.

\begin{tabular}{|c|c|c|c|c|c|c|c|c|c|c|}
\hline & & \multicolumn{4}{|l|}{ TSP } & \multicolumn{4}{|l|}{ PM2.5 } & \multirow[t]{2}{*}{$\mathrm{PM}_{2.5} / \mathrm{TSP}$} \\
\hline & & TSP & OC & $\mathrm{EC}$ & $\mathrm{OC} / \mathrm{EC}$ & $\mathrm{PM}_{2.5}$ & OC & EC & OC/EC & \\
\hline \multirow[t]{4}{*}{ Day and night } & Mean & 125.4 & 7.3 & 2.5 & 3.1 & 92.3 & 5.2 & 2.0 & 2.7 & 0.75 \\
\hline & Maximum & 198.5 & 14.4 & 4.7 & 6.2 & 194.3 & 11.0 & 3.9 & 4.0 & 0.99 \\
\hline & Minimum & 46.1 & 3.1 & 0.8 & 2.0 & 33.3 & 1.8 & 0.6 & 2.0 & 0.45 \\
\hline & $\mathrm{CV}^{\mathrm{a}}$ & 0.4 & 0.4 & 0.5 & 0.3 & 0.4 & 0.5 & 0.5 & 0.2 & 0.18 \\
\hline \multirow[t]{4}{*}{ Day } & Mean & 135.3 & 8.7 & 2.7 & 3.3 & 101.9 & 6.7 & 2.3 & 3.0 & 0.77 \\
\hline & Maximum & 291.1 & 19.2 & 5.0 & 8.6 & 203.9 & 18.3 & 4.8 & 5.1 & 0.91 \\
\hline & Minimum & 47.0 & 2.6 & 0.8 & 1.9 & 31.6 & 1.9 & 0.6 & 2.0 & 0.34 \\
\hline & $\mathrm{CV}^{\mathrm{a}}$ & 0.4 & 0.5 & 0.4 & 0.4 & 0.4 & 0.6 & 0.6 & 0.2 & 0.18 \\
\hline \multirow[t]{4}{*}{ Night } & Mean & 117.0 & 6.9 & 2.6 & 2.9 & 83.5 & 4.2 & 1.8 & 2.6 & 0.72 \\
\hline & Maximum & 222.0 & 14.0 & 4.6 & 7.5 & 184.7 & 10.0 & 4.0 & 5.6 & 0.99 \\
\hline & Minimum & 45.2 & 1.9 & 0.8 & 1.0 & 28.8 & 0.7 & 0.3 & 1.5 & 0.51 \\
\hline & $\mathrm{CV}^{\mathrm{a}}$ & 0.4 & 0.4 & 0.5 & 0.4 & 0.4 & 0.6 & 0.6 & 0.3 & 0.20 \\
\hline
\end{tabular}

a $\mathrm{CV}$ : Coefficient of variation.

was 0.75 , ranging from 0.45 to 0.99 , which indicates that fine particulate matter is a primary pollutant in the region.

Daily mean concentrations of OC and EC were 7.3 and $2.5 \mu \mathrm{g} \mathrm{m}^{-3}$ in TSP, while 5.2 and $2.0 \mu \mathrm{g} \mathrm{m}^{-3}$ in $\mathrm{PM}_{2.5}$, respectively. OC and EC concentrations accounted for $5.8 \%$ and $2.0 \%$ of the TSP mass concentration, while $5.6 \%$ and $2.2 \%$ for $\mathrm{PM}_{2.5}$. The contributions of carbonaceous species to particulate matter were notably lower than that in Chinese cities (Cao et al., 2007), and comparable with that at coastal background region, such as at Tuoji Island (Wang et al., 2014). The contribution of OC in $\mathrm{PM}_{2.5}$ was slightly lower than that in TSP, while the contribution of EC was slightly higher. Our finding is in agreement with the Qinghai Lake region (Zhang et al., 2014a). The ratios of OC to EC were 3.1 (2.06.2) for TSP and 2.7 (2.0-4.0) for $\mathrm{PM}_{2.5}$, respectively. The signals consist with the finding that EC abundances in fine particulate matter (Duarte et al., 2008). In addition, the results of the Kolmogorov-Smirnov test shows that the particulate matter and carbonaceous aerosol concentrations were normally distributed, implying that they were supported by a relative stable source emission and/or environmental condition (Wang et al., 2014). The aspect was also characterized by respective smaller coefficient of variation as shown in Table 1.

Supporting information Table S1 showed a comparison of $\mathrm{PM}_{2.5}, \mathrm{OC}$, EC concentration levels and $\mathrm{OC} / \mathrm{EC}$ ratios in the present study with those previously reported from other coastal areas in China. It can be seen clearly that the summer $\mathrm{PM}_{2.5}$ concentration in the Yellow River Delta was higher than those in other coastal areas in China, whereas OC and EC concentrations were found lower, such as $10.2 \mu \mathrm{g} \mathrm{m}^{-3}$ and $5.5 \mu \mathrm{g} \mathrm{m}^{-3}$ in Tianjin (Gu et al., 2010), $9.3 \mu \mathrm{g} \mathrm{m} \mathrm{m}^{-3}$ and $2.3 \mu \mathrm{g} \mathrm{m}^{-3}$ in Shanghai (Feng et al., 2009), $9.6 \mu \mathrm{g} \mathrm{m}^{-3}$ and $2.2 \mu \mathrm{g} \mathrm{m}^{-3}$ in Xiamen (Zhang et al., 2011) and comparable with those in coastal background sites, such as $3.5 \mu \mathrm{g} \mathrm{m}^{-3}$ and $1.1 \mu \mathrm{g} \mathrm{m}^{-3}$ in Changdao Island (Feng et al., 2007), $5.7 \mu \mathrm{g} \mathrm{m}^{-3}$ and $1.7 \mu \mathrm{g} \mathrm{m}^{-3}$ in Tuoji Island (Wang et al., 2014), and $2.5 \mu \mathrm{g} \mathrm{m}^{-3}$ and $0.8 \mu \mathrm{g} \mathrm{m}^{-3}$ in Ningbo (Liu et al., 2013). It suggests the weak association of combustion sources to the levels of carbonaceous species in the Yellow River Delta and/or Chinese coastal background areas as compared to those in the coastal cities in China. On the other hand, the OC/EC ratio $(2.7 \pm 0.5)$ in the Yellow River Delta was higher than that in Tianjin (1.8), and was lower than that in the other southern sites listed in SI Table S1. It reflects that low temperature combustion emission, such as biomass combustion primary sources and/or the formation of secondary organic carbon contributed more carbonaceous aerosols in the Yellow River Delta than in Tianjin (Li et al., 2014).

\subsection{Intraday fluctuation of TSP, $P M_{2.5}$ and carbonaceous species}

Table 1 also lists those statistical values of OC, EC, TSP and $\mathrm{PM}_{2.5}$ concentrations in the day time and night time. In general, these concentrations were higher in daytime than in nighttime. The average day-tonight ratios $(\mathrm{D} / \mathrm{N})$ for TSP and $\mathrm{PM}_{2.5}$ were 1.28 and 1.32 , respectively, suggesting the relative strong emission of fine particulates in the day time, which is largely attributed to the anthropogenic activities. Similarly, the D/N ratios for OC and EC were 1.45 and 1.18 in TSP, and 2.54 and 2.09 in $\mathrm{PM}_{2.5}$, respectively. The difference between these $\mathrm{D} / \mathrm{N}$ ratios is an indication that $\mathrm{OC}$ and EC originated from different sources. The slightly higher $\mathrm{D} / \mathrm{N}$ ratio for OC than for EC in both TSP and $\mathrm{PM}_{2.5}$ may be ascribed to the formation of SOC under intense photochemical conditions in daytime, which is similar to those (1.4 and 1.1 for OC and EC) found in Shanghai (Cao et al., 2013). The D/N ratios for both OC and EC in $\mathrm{PM}_{2.5}$ were near twice that in TSP, indicating more notable intraday fluctuation of carbonaceous species in fine particles.

To identify the co-emission and/or transport of these atmospheric species, daytime and nighttime concentration series were correlated and listed in SI Table S2. Generally, the high correlations of the atmospheric species suggested their strong co-emission and/or transport patterns. TSP and $\mathrm{PM}_{2.5}$ showed higher correlation with each other and also with carbonaceous species in the night time as compared to the day time. It suggests weak co-emission signal of particulate matter and carbonaceous species in daytime, which can be attributed to the contribution of emission unassociated with combustion (such as build activities, dust) on the particulate matter in the Yellow River Delta. The correlations between OC and EC in TSP were the same in the day and night, while the correlations of carbonaceous species in $\mathrm{PM}_{2.5}$ were lower in day time than in night time. The lower correlation in the day time is indicating a stronger formation of SOC in the day time than in the night time.

The temporal variations of $6 \mathrm{~h}$ time interval particulate matter and carbonaceous species concentrations collected during two periods of three days are shown in SI Fig. S2. Generally, the contaminant burdens during the first period were higher than that in the second period, and the concentrations increased from nightfall to the next afternoon. The high concentrations in the first sampling period were ascribed to the air masses of the period from south source region and encountered agricultural field burning as described later. During the second sampling period, winds blowing from clear sea bring maritime air to the Yellow River Delta and this presumably dilutes and disperses the air pollutants, resulting in relative low concentrations in the sampling period. The lowest concentrations at nightfall (18:00-00:00) may be explained by decrease of domestic, industrial and traffic emissions during the period of time. In the next time period (00:00-06:00), relative high concentrations in night were ascribed from increasing emission and/or obvious accumulation of contaminations and the formation of SOC under more stable atmospheric conditions than that at nightfall (Kim et al., 2012). The concentrations increased continuously and reached at its peak in the afternoon hours (12:00-18:00). The highest concentrations were in agreement with increasing emission during daytime. Slightly high OC/EC ratios at afternoon suggested an additional contribution of photochemical SOC formation to the OC concentrations as shown in SI Fig. S3. 


\subsection{Source apportionment of carbonaceous species in $P M_{2.5}$}

In order to compensate the excess ${ }^{14} \mathrm{C}$ produced by nuclear bomb testing in 1950 and 1960s, the fraction of modern carbon $\left(f_{m}\right)$ given by AMS was further converted into the fraction of contemporary carbon $\left(f_{c}\right)$ by normalizing with a conversion factor of 1.06 and 1.10 for EC and OC (Liu et al., 2014). The $\mathrm{f}_{\mathrm{c}}$ values in the samples were defined as $\mathrm{f}_{\mathrm{c}}=$ $\mathrm{f}_{\mathrm{m}} / 1.10$ for $E C, \mathrm{f}_{\mathrm{c}}=\mathrm{f}_{\mathrm{m}} / 1.06$ for OC, and the fraction of fossil $\left(\mathrm{f}_{\mathrm{f}}\right)$ was defined as $\mathrm{f}_{\mathrm{f}}=1-\mathrm{f}_{\mathrm{c}}$. Two combined samples representing different sources were selected to analyze ${ }^{14} \mathrm{C}$ of WINSOC and EC. They were collected on the 3rd, and 11th June, showing prevailing south and north wind, respectively. The first sample was merged by four 6-hourly samples, and the other sample was merged by two 12-hourly samples. The values of ${ }^{14} \mathrm{C}$ in the WINSOC and $\mathrm{EC}$ for the samples with different wind directions are listed in Table 2.

The values for $f_{c}$ (WINSOC) ranged from 0.63 to 0.74 with a mean of 0.69 , which indicates that contemporary carbon sources (biogenic and biomass burning) were the primary sources of WINSOC at the Yellow River Delta. The $\mathrm{f}_{c}(\mathrm{EC})$ values ranged between 0.48 and 0.59 with a mean of 0.54 , which were lower than the corresponding $\mathrm{f}_{\mathrm{c}}$ (WINSOC) values, demonstrating relative larger contribution of non-fossil source emission to WINSOC. Higher contributions of contemporary carbon sources to WINSOC than EC were also found at background sites in the Yangtze River Delta (56\% and 40\%) (Liu et al., 2013) and South China ( $83 \%$ and $62 \%$ ) (Zhang et al., 2014b). The contributions of contemporary carbon sources to EC at these background sites were significantly lower than those in the Chinese cities, such as $17 \%$ in Beijing and Shanghai (Chen et al., 2013; Sun et al., 2012), 13\% in Xiamen (Chen et al., 2013), and 29\% in Guangzhou (Liu et al., 2014).

During the sampling period, the synoptic system at the sampling site was dominated by southerly or southeast wind under the East Asian summer monsoon as a back trajectory cluster map during the sampling period (Fig. S1). The $\mathrm{f}_{\mathrm{c}}$ (WINSOC) and $\mathrm{f}_{\mathrm{c}}(\mathrm{EC})$ were 0.74 and 0.59 on 3rd June, indicating $74 \%$ and $59 \%$ of the contribution of biogenic and biomass burning emission to the carbonaceous species, respectively, while the contribution of fossil source to WINSOC and EC only was $26 \%$ and $41 \%$, respectively. On the day, the OC and EC concentrations reached a peak for both $\mathrm{PM}_{2.5}$ (14.0 and $4.6 \mu \mathrm{g} \mathrm{m}^{-3}$ ) and TSP (17.7 and $5.0 \mu \mathrm{g} \mathrm{m}^{-3}$ ). The back trajectory showed that the air masses passed through the area with intensive open agricultural burning activities in the $\mathrm{SHJ}$ region under the south wind (Fig. 2). As the upwind area, the $\mathrm{SHJ}$ region has been estimated as a major emission area of biomass burning (Zhao et al., 2012). Open burning of agricultural wastes in summer in the SHJ region contributed largely to the concentration burden and atmospheric transport of carbonaceous aerosol in the Bohai Rim (Wang et al., 2014).

In comparison with WINSOC and EC on 3rd June, the concentrations of carbonaceous species were very low on 11th June, when the air masses come from the north and pass through the BTH region before reaching the sampling site as shown in Fig. $3 .{ }^{14} \mathrm{C}$ results indicated that the contribution of biomass-burning and biogenic emissions to the WINSOC and EC accounted for $63 \%$ and $48 \%$, respectively, which was $10 \%$ lower than the south wind. In recent years, the BTH region has been considered as the most severely polluted area in China and industrial emissions, coal burning and automobile emissions are considered as major contributors (Pui et al., 2014; Sun et al., 2014). The high contribution of biomass-burning emission suggests weak impact of

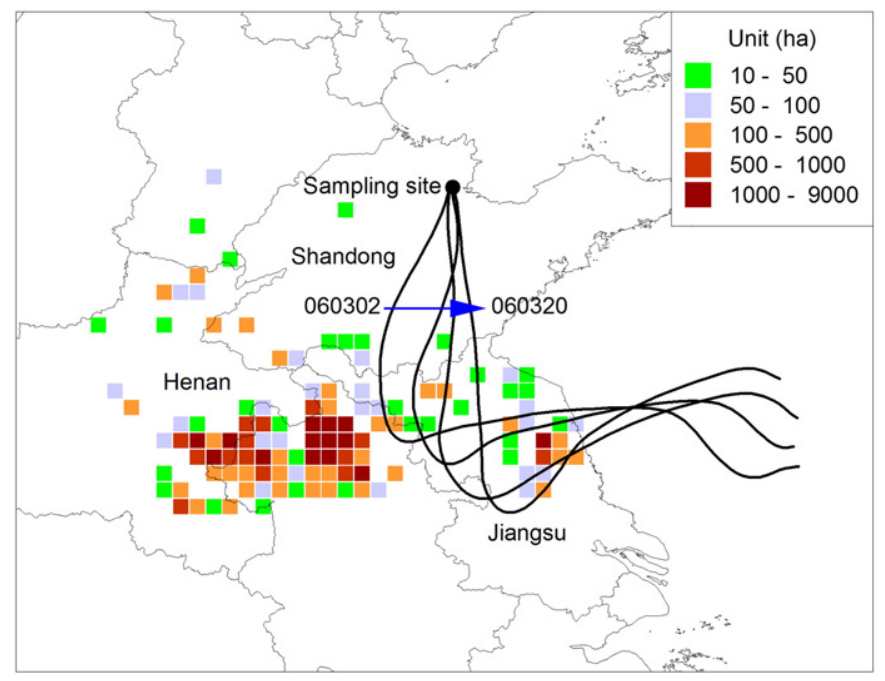

Fig. 2. 72-h back trajectories (black lines) at 02:00, 08:00, 14:00, and 20:00 and burned area on 3 June, 2013.

carbonaceous aerosols emitted from the BTH region on the air quality at the sampling site.

The contemporary carbon concentrations of the WINSOC and EC were 3.7 and $2.7 \mu \mathrm{g} \mathrm{m}^{-3}$, and the fossil fuel carbon concentrations of the WINSOC and EC were 1.3 and $1.9 \mu \mathrm{g} \mathrm{m}^{-3}$ on June 3rd, prevailing south wind. While the contemporary carbon concentrations of the WINSOC and EC were 0.6 and $0.4 \mu \mathrm{g} \mathrm{m}^{-3}$, and the fossil fuel carbon concentrations of the WINSOC and EC were 0.4 and $0.4 \mu \mathrm{g} \mathrm{m}^{-3}$ on June 11 th prevailing north wind. The huge difference of the concentrations can be attributed to the biogenic origin, such as biomass combustion in the $\mathrm{SHJ}$ region.

To confirm the contribution of open burning of agricultural wastes on carbonaceous aerosol, a scatter plot showing daily OC and EC concentrations against burned area during the sampling period was obtained and presented in Fig. 4. When the burned area is lesser, the linear of $\mathrm{OC}$ and EC is not obvious, though the linear grows with the burned area increasing. Supporting information Figs. S4-6 showed 72-h back trajectories and burned area on 4th, 8th and 13th June, 2013, respectively. High OC and EC concentrations were found when air masses passing through the sampling site along with agricultural waste burning, such as on 3rd (see Fig. 2), 4th (see SI Fig. S4) and 13th June (SI Fig. S5). Similarly, the relative low concentrations of $\mathrm{OC}$ and EC were presented when air masses via the sampling site were not experienced with burned areas, such as on 8th June (see SI Fig. S5). It shows that the significant contribution of open agricultural burning on the concentration levels of carbonaceous aerosols under a favorable meteorological condition.

\subsection{Source area identification}

The domain of interest extended from $104^{\circ} \mathrm{E}$ to $130^{\circ} \mathrm{E}$ and $30^{\circ} \mathrm{N}$ to $46^{\circ} \mathrm{N}$, which was divided into 1836 grid cells of $0.5^{\circ} \times 0.5^{\circ}$ latitude and longitude according to the geographical locations of 72-h back trajectory endpoints during the sampling period. Fig. 5 shows the spatial patterns of PSCF values of $\mathrm{PM}_{2.5}$, and $\mathrm{OC}$ and $\mathrm{EC}$ in the $\mathrm{PM}_{2.5}$ samples. In

Table 2

The values of ${ }^{14} \mathrm{C}$ in the WINSOC and EC for the samples with different wind directions.

\begin{tabular}{|c|c|c|c|c|c|c|c|}
\hline Date & Wind direction & WINSOC $\left(\mu \mathrm{g} \mathrm{m}^{-3}\right)$ & $\mathrm{EC}\left(\mu \mathrm{g} \mathrm{m}^{-3}\right)$ & $\mathrm{f}_{\mathrm{c}}$ (WINSOC) & $\mathrm{f}_{\mathrm{f}}($ WINSOC) & $\mathrm{f}_{\mathrm{c}}(\mathrm{EC})$ & $\mathrm{f}_{\mathrm{f}}(\mathrm{EC})$ \\
\hline 3rd, June & South & 5.0 & 4.6 & 0.74 & 0.26 & 0.59 & 0.41 \\
\hline \multirow[t]{2}{*}{ 11th, June } & North & 1.0 & 0.8 & 0.63 & 0.37 & 0.48 & 0.52 \\
\hline & Average & - & - & 0.69 & 0.32 & 0.54 & 0.47 \\
\hline
\end{tabular}




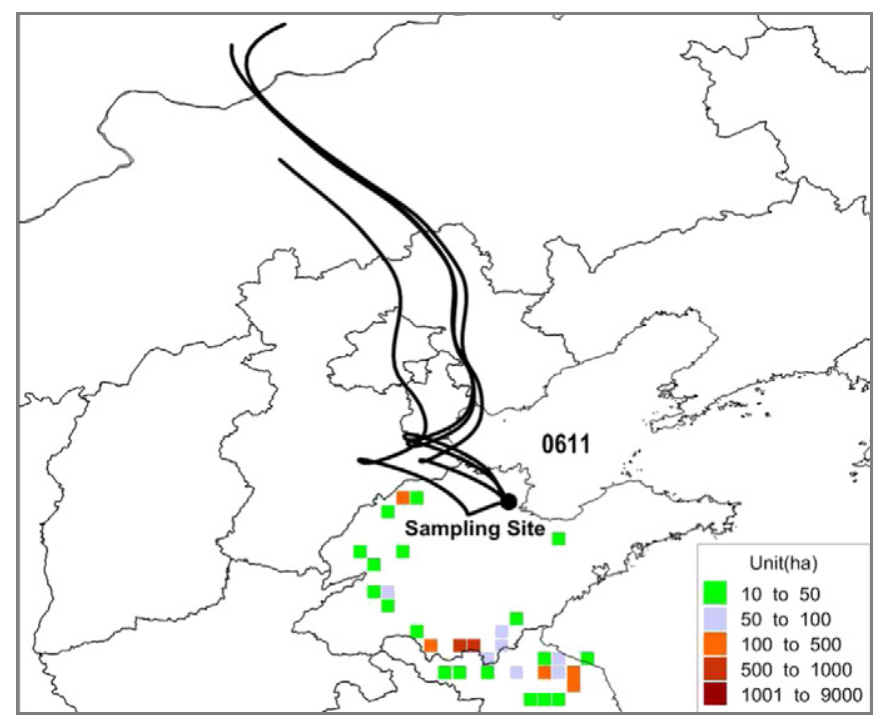

Fig. 3. 72-h back trajectories (black lines) at 02:00, 08:00, 14:00, and 20:00 and burned area on 11 June, 2013.

general, the potential source areas with high PSCF values for $\mathrm{PM}_{2.5}$, OC and EC were in the Southern side. Although the northern BTH region has been identified as a main source area in the Bohai Rim (Zhao et al., 2012), the prevailing southerly winds during sampling period deterred the atmospheric transport of pollutants emitted from the BTH region to the Yellow River Delta. Those areas bordering Shandong, Jiangsu, Anhui and Henan province were mainly identified as potential source areas for $\mathrm{PM}_{2.5}$, OC and EC, in particular for EC. It indicates that the combustion emission in the area affected largely concentration levels of EC in the Yellow River Delta.

Fig. 6 shows accumulated burned area during the sampling period. Most intensive agricultural waste open burning activities were found in the contiguous area, which is in agreement with the finding as mentioned above. The spatial patterns of the potential source areas were slightly different for $\mathrm{PM}_{2.5}, \mathrm{OC}$ and $\mathrm{EC}$, which are attributed to their different origins. For example, Dongying city was considered as a potential source area with high probability for both $\mathrm{PM}_{2.5}$ and $\mathrm{OC}$ as shown in Fig. 5. However, the city was not highlighted as a significant source area for EC. Dongying is located about $60 \mathrm{~km}$ southwest of the sampling site, and is the nearest city from the sampling site. It is a medium city, and the industry is relatively underdeveloped, which contributed to that the EC source, such as vehicle emission and combustion, was less, compared with other big cities. As a result, non-combustion emissions (such as buildings) and high OC emission (such as biomass burning)

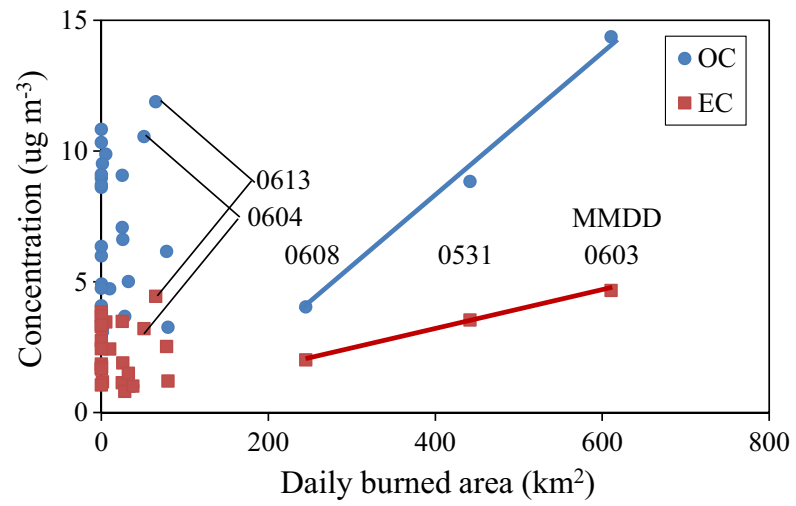

Fig. 4. Scatterplot of daily OC, EC concentrations and burned area during the sampling period.

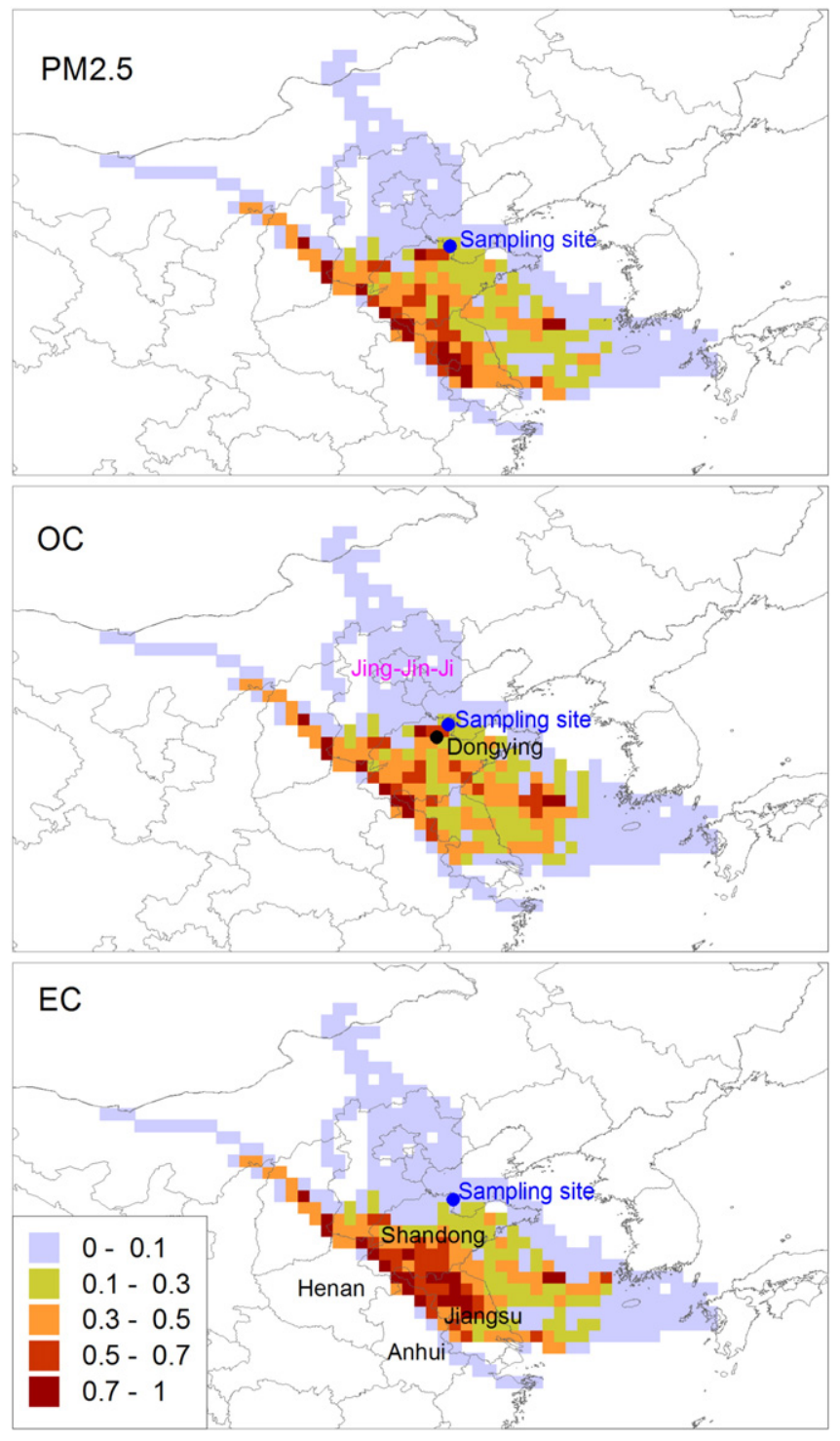

Fig. 5. Spatial distributions of PSCF values of $\mathrm{PM}_{2.5}$, and OC and $\mathrm{EC}$ in $\mathrm{PM}_{2.5}$.

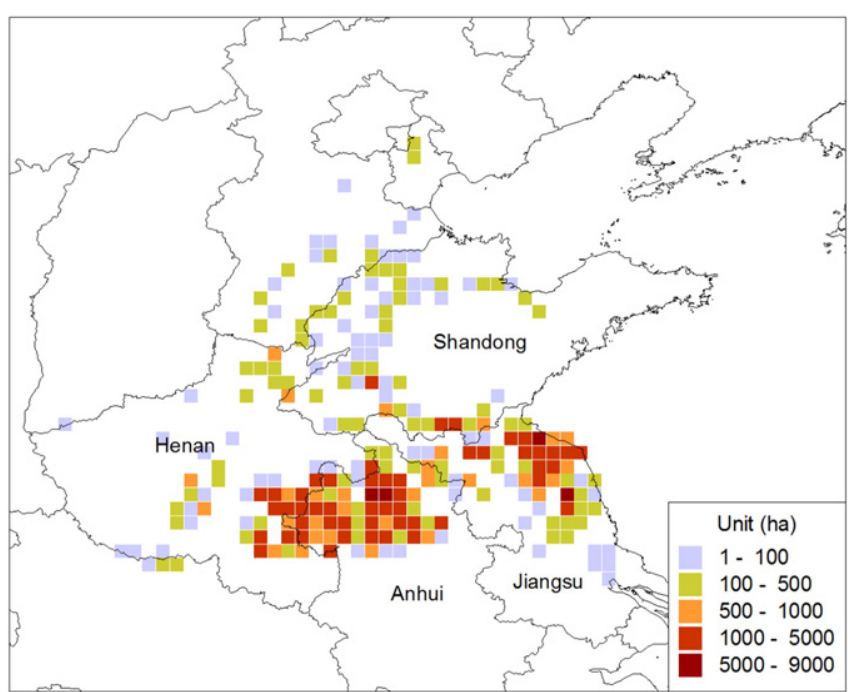

Fig. 6. Accumulated burned areas during the sampling period. 
in the city contributed partly fine particulate matter and OC burden in the Yellow River Delta.

\section{Conclusions}

In this study, carbonaceous aerosols in TSP and $\mathrm{PM}_{2.5}$ samples collected at the Yellow River Delta, China in summer, 2013 were analyzed to assess the temporal variation of particulate matter and carbonaceous aerosol concentrations associated with source emissions and environmental factors. The TSP and $\mathrm{PM}_{2.5}$ concentrations exceeded the corresponding national standards, and were considerably higher compared with other Chinese coastal areas. OC and EC concentrations were contributed to $5.8 \%$ and $2.0 \%$ of the TSP mass concentration and $5.6 \%$ and $2.2 \%$ for $\mathrm{PM}_{2.5}$, respectively. The contribution was comparable to that at other background regions in Bohai Rim. The concentrations of particulate matter and carbonaceous species in the Yellow River Delta were higher in daytime than in nighttime, which was associated with emission of anthropogenic activities. Due to the costly measurement of ${ }^{14} \mathrm{C}$, two merged samples were carefully selected based on predetermined concentration levels of carbonaceous species and meteorological conditions. Demonstrated by the ${ }^{14} \mathrm{C}$ and PSCF results, agricultural waste open burning in the contiguous area of the $\mathrm{SHJ}$ region was concluded as a main contributor of WISOC and EC concentrations in the Yellow River Delta in summer.

Controlling fossil-fuel combustion is highlighted as a major action to improve air quality in the cities of Bohai Rim, China (Chen et al., 2013; Sun et al., 2012). Our radiocarbon analysis indicates more pronounced signal contemporary carbon sources and the need for more stringent control of agricultural waste open burning emission on the regional scale. These data are very helpful to better constitute and implement relevant regulation policy associated with emissions to improve air quality efficiently in the Bohai Rim, China.

\section{Acknowledgments}

This work was supported by the Promotive Research Foundation for Excellent Young and Middle-aged Scientists of Shandong Province (No. BS2012HZ028), the CAS Strategic Priority Research Program (Nos. XDB05020207, XDB05030303 and XDA11020402), and the Natural Scientific Foundation of China (Nos. 41101495 and 41471413). The authors gratefully acknowledge the National Oceanic and Atmospheric Administration's Air Resources Laboratory for providing the HYSPLIT transport model and the READY website (http://www.arl.noaa.gov/ ready.html).

\section{Appendix A. Supplementary data}

Supplementary data associated with this article can be found in the online version, at http://dx.doi.org/10.1016/j.scitotenv.2015.01.113.

\section{References}

Anenberg, S.C., Schwartz, J., Shindell, D., Amann, M., Faluvegi, G., Klimont, Z., et al., 2012 Global air quality and health co-benefits of mitigating near-term climate change through methane and black carbon emission controls. Environ. Health Perspect. $120,831$.

Boynard, A., Clerbaux, C., Clarisse, L., Safieddine, S., Pommier, M., Van Damme, M., et al., 2014. First simultaneous space measurements of atmospheric pollutants in the boundary layer from IASI: a case study in the North China Plain. Geophys. Res. Lett. $41,645-651$.

Cao, J.J., Lee, S.C., Chow, J.C., Watson, J.G., Ho, K.F., Zhang, R.J., et al., 2007. Spatial and seasonal distributions of carbonaceous aerosols over China. J. Geophys. Res. 112, D22S11.

Cao, J.J., Zhu, C.S., Tie, X.X., Geng, F.H., Xu, H.M., Ho, S.S.H., et al., 2013. Characteristics and sources of carbonaceous aerosols from Shanghai, China. Atmos. Chem. Phys. 13, 803-817.

Chen, B., Andersson, A., Lee, M., Kirillova, E.N., Xiao, Q., Kruså, M., et al., 2013. Source forensics of black carbon aerosols from China. Environ. Sci. Technol. 47, 9102-9108.

Cheng, Y., Engling, G., He, K.B., Duan, F.K., Ma, Y.L., Du, Z.Y., et al., 2013. Biomass burning contribution to Beijing aerosol. Atmos. Chem. Phys. 13, 7765-7781.
Chung, C.E., Ramanathan, V., Decremer, D., 2012. Observationally constrained estimates of carbonaceous aerosol radiative forcing. Proc. Natl. Acad. Sci. U. S. A. 109, 11624-11629.

Draxler, R.R., Rolph, G.D., 2003. HYSPLIT (HYbrid Single-Particle Lagrangian Integrated Trajectory) Model access via NOAA ARL READY Website. (http://www.arl.noaa.gov/ ready/hysplit4.html). Silver Spring, MD, NOAA Air Resources Laboratory.

Duarte, R.M.B.O., Mieiro, C.L., Penetra, A., Pio, C.A., Duarte, A.C., 2008. Carbonaceous materials in size-segregated atmospheric aerosols from urban and coastal-rural areas at the Western European Coast. Atmos. Res. 90, 253-263.

Fang, G.-C., Wu, Y.-S., Chou, T.-Y., Lee, C.-Z., 2008. Organic carbon and elemental carbon in Asia: a review from 1996 to 2006. J. Hazard. Mater. 150, 231-237.

Feng, J., Guo, Z., Chan, C.K., Fang, M., 2007. Properties of organic matter in PM2.5 at Changdao Island, China-a rural site in the transport path of the Asian continental outflow. Atmos. Environ. 41, 1924-1935.

Feng, Y., Chen, Y., Guo, H., Zhi, G., Xiong, S., Li, J., et al., 2009. Characteristics of organic and elemental carbon in PM2.5 samples in Shanghai, China. Atmos. Res. 92, 434-442.

Giglio, L., Randerson, J.T., van der Werf, G.R., 2013. Analysis of daily, monthly, and annual burned area using the fourth-generation global fire emissions database (GFED4). J. Geophys. Res. Biogeosci. 118, 317-328.

Gu, J., Bai, Z., Liu, A., Wu, L., Xie, Y., Li, W., et al., 2010. Characterization of atmospheric organic carbon and element carbon of $\mathrm{PM}_{2.5}$ and $\mathrm{PM}_{10}$ at Tianjin, China. Aerosol Air Qual. Res. 10, 167-176.

Han, G., Luo, Y., Li, D., Xia, J., Xing, Q., Yu, J., 2014. Ecosystem photosynthesis regulates soil respiration on a diurnal scale with a short-term time lag in a coastal wetland. Soil Biol. Biochem. 68, 85-94.

Huang, R.-J., Zhang, Y., Bozzetti, C., Ho, K.-F., Cao, J.-J., Han, Y., et al., 2014. High secondary aerosol contribution to particulate pollution during haze events in China. Nature 514, 218-222.

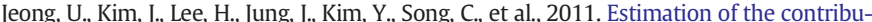
tions of long range transported aerosol in East Asia to carbonaceous aerosol and PM concentrations in Seoul, Korea using highly time resolved measurements: a PSCF model approach. J. Environ. Monit. 13, 1905-1918.

Kim, W., Lee, H., Kim, J., Jeong, U., Kweon, J., 2012. Estimation of seasonal diurnal variations in primary and secondary organic carbon concentrations in the urban atmosphere: EC tracer and multiple regression approaches. Atmos. Environ. 56, 101-108.

Li, J., Song, Y., Mao, Y., Mao, Z., Wu, Y., Li, M., et al., 2014. Chemical characteristics and source apportionment of PM2.5 during the harvest season in eastern China's agricultural regions. Atmos. Environ. 92, 442-448.

Liu, D., Li, J., Zhang, Y., Xu, Y., Liu, X., Ding, P., et al., 2013. The use of levoglucosan and radiocarbon for source apportionment of PM2.5 carbonaceous aerosols at a background site in East China. Environ. Sci. Technol. 47, 10454-10461.

Liu, J., Li, J., Zhang, Y., Liu, D., Ding, P., Shen, C., et al., 2014. Source apportionment using radiocarbon and organic tracers for PM2.5 carbonaceous aerosols in Guangzhou, South China: contrasting local- and regional-scale haze events. Environ. Sci. Technol. 48, 12002-12011.

Mahowald, N., 2011. Aerosol indirect effect on biogeochemical cycles and climate. Science 334, 794-796.

Pui, D.Y.H., Chen, S.-C., Zuo, Z., 2014. PM2.5 in China: measurements, sources, visibility and health effects, and mitigation. Particuology 13,1-26.

Puxbaum, H., Caseiro, A., Sánchez-Ochoa, A., Kasper-Giebl, A., Claeys, M., Gelencsér, A., et al., 2007. Levoglucosan levels at background sites in Europe for assessing the impact of biomass combustion on the European aerosol background. J. Geophys. Res. Atmos. 112, D23S05.

Sun, X., Hu, M., Guo, S., Liu, K., Zhou, L., 2012. 14C-Based source assessment of carbonaceous aerosols at a rural site. Atmos. Environ. 50, 36-40.

Sun, Y., Jiang, Q., Wang, Z., Fu, P., Li, J., Yang, T., et al., 2014. Investigation of the sources and evolution processes of severe haze pollution in Beijing in January 2013. J. Geophys. Res. Atmos. 119 (2014JD021641)

Wang, Q., Shao, M., Zhang, Y., Wei, Y., Hu, M., Guo, S., 2009a. Source apportionment of fine organic aerosols in Beijing. Atmos. Chem. Phys. 9, 8573-8585.

Wang, Y.Q., Zhang, X.Y., Draxler, R.R., 2009b. TrajStat: GIS-based software that uses various trajectory statistical analysis methods to identify potential sources from longterm air pollution measurement data. Environ. Model Softw. 24, 938-939.

Wang, X., Chen, Y., Tian, C., Huang, G., Fang, Y., Zhang, F., et al., 2014. Impact of agricultural waste burning in the Shandong Peninsula on carbonaceous aerosols in the Bohai Rim, China. Sci. Total Environ. 481, 311-316.

Xin, J., Wang, L., Wang, Y., Li, Z., Wang, P., 2011. Trends in aerosol optical properties over the Bohai Rim in Northeast China from 2004 to 2010. Atmos. Environ. 45, 6317-6325.

Zhang, G., Li, J., Li, X.-D., Xu, Y., Guo, L.-L., Tang, J.-H., et al., 2010. Impact of anthropogenic emissions and open biomass burning on regional carbonaceous aerosols in South China. Environ. Pollut. 158, 3392-3400.

Zhang, F., Zhao, J., Chen, J., Xu, Y., Xu, L., 2011. Pollution characteristics of organic and elemental carbon in PM2.5 in Xiamen, China. J. Environ. Sci. (China) 23, 1342-1349.

Zhang, N., Cao, J., Liu, S., Zhao, Z., Xu, H., Xiao, S., 2014a. Chemical composition and sources of PM2.5 and TSP collected at Qinghai Lake during summertime. Atmos. Res. 138, 213-222.

Zhang, Y.-L., Li, J., Zhang, G., Zotter, P., Huang, R.-J., Tang, J.-H., et al., 2014b. Radiocarbonbased source apportionment of carbonaceous aerosols at a regional background site on Hainan Island, South China. Environ. Sci. Technol. 48, 2651-2659.

Zhao, B., Wang, P., Ma, J.Z., Zhu, S., Pozzer, A., Li, W., 2012. A high-resolution emission inventory of primary pollutants for the Huabei region, China. Atmos. Chem. Phys. 12, 481-501. 